\title{
The Role of Indonesian Red Cross in Disaster Management in Medan
}

\author{
Rudi Kristian P.Manurung1/ Asima Yanty Siahaan²
}

\author{
Department of Public Administration \\ Faculty of Political and Social Sciences \\ University of Sumatera Utara, Medan, Indonesia \\ rudimanurung17@yahoo.com ${ }^{1}$, asimayantysiahaan@gmail.com ${ }^{2}$
}

\begin{abstract}
Disaster management as part of a disaster management policy is not only the responsibility of the government. The public through institutions and community organizations participate and have significant roles and responsibilities in disaster management. This paper discusses the role, challenges and strategies of PMI as civic organization participating in disaster management in Medan. This study uses qualitative data collection through interviews with Medan Indonesia Red Cross and disaster victims. Findings of this study reveal that PMI's strong organizational structure, and the established Standard Operating Procedures in disaster management, as well as available equipment and volunteers contribute to the significant roles and achievement of PMI in dealing with the frequent disasters in Medan especially in the emergency phase of disaster. On the other hand, PMI is yet to have effective coordination with the Regional Disaster Management Agency (BPBD) due to the recent establishment of Regional Disaster Management Agency with its institutional challenges which obstructs its performance.
\end{abstract}

Keywords: civil, disaster management, emergency

\section{INTRODUCTION}

Disaster and its impact is a form of reality to test the policy foundation for Disaster Mitigation in Indonesia. As the collision to see the extent to which governments and communities can face and withstand the impact / cost incurred. Attendance should disaster is not something that should be grateful for, but if you want to see the development capabilities of our disaster management, disaster is the right thing to be invited so that we can see the extent of our ability to cope with disasters and can survive even hit back at the disaster.

Disasters caused by natural and man. Such as natural disasters, social upheavals and nonnatural disasters caused by humans. Indonesia's position is geologically located between three major tectonic plates, the Indo-Australian Plate, the Eurasian Plate and the Pacific Plate. Loui (in Kodoatie, 2006: 46), the meeting of these plates make Indonesia as one of the countries most many geological changes in the world. The world's siege of three tectonic plates that form the Pacific Ring of Fire or the Pacific Ring of Fire, which is also a series of lines of active volcanoes in the world that can erupt at any time and lead to calamity. In the path of the fire ring there are 40 percent who are still active volcano. Center for Volcanology and Geological Hazard Mitigation (PVMBG) noted we had approximately 127 active volcanoes, which means anytime and anywhere, we will be dealing with the volcano, but unfortunately there is no tool can be sure when the mountain will eruptions / erupt.

United Nations International Strategy for Disaster Reduction (UNISDR / Agency of the United Nations (UN) International Strategy for Disaster Reduction) said that Indonesia is a country that has the highest risk of natural disasters in the world. This is because the high number of people exposed or have the highest risk to the earthquake, tsunami, volcanic eruptions, floods, landslides, drought, and wildfires in the range of 5.4 million people. (Hasan, 2012: 14). For example, there are still many residents who live on the riverbanks (Jakarta), on the edge of the river and the Babura 
Deli (Medan), a location that was close to the volcano and on the waterfront.

Act No. 24 of 2007 on Disaster Management, regulates the authority of disaster management plans, where the authority of the National exist in the National Disaster Management Agency (BNPB), to the provincial level to the Regional Disaster Management Agency (BPBD) and for the district / city level in Disaster Management Agency District / City. (Manurung, 2014: 2) Thus, this institution is present when the first organization of disaster management and as coordinator in the implementation of disaster management itself.

Besides BNPB, BPBDs BPBDs Provincial and District / Municipal Government, through BNPB also organize community's role in disaster management. The role is set in Perka BNPB No. 11 Year 2014 on Community Participation in Disaster Relief. The public can show its role through directly involved when a disaster occurs and through the establishment of the organization. The formation of the organization as a forum for public awareness in disaster management.

People who care for disaster management in the region tends to be active in organizations related to the disaster. Community by volunteering to participate actively in disaster unconditionally, they are what is called a volunteer or volunteers. These volunteers go jump in disaster management. Volunteer falls through the intermediary of humanitarian organizations one Indonesian Red Cross.

The Indonesian Red Cross (PMI) is an organization that collected within international organizations (the International Federation of Red Cross and Red Cressent) engaged in humanitarian service. The main focus of this organization is a medical or non-medical services to victims of natural disasters and social disasters.

In Indonesia, PMI has been active since September 1945 had played a role in providing medical assistance since the time of the battle to maintain the independence of Indonesia, until the era of peace as it is today, the Indonesian Red Cross remained consistently making active efforts in the promotion of public health in normal conditions, until emergency response services in exceptional conditions such as natural disasters.

Services PMI is generally composed of three services, namely Disaster Management Services, Health Services and Donor Services. As for doing ministry, PMI has seven basic principles that are used as the basis in providing assistance, namely humanity, similarity, Neutrality, Independence, Voluntary, unity, and universality that aims to make the organization remains faithful to provide assistance to a fellow human being in need without distinction -bedakan victims according to any background and remain neutral on political motives everywhere and Indonesia.

The fundamental principles of the Red Cross described as follows:

1. Humanity Movement of Red Cross and Red Crescent Societies was founded based on the desire to give aid without differentiating wounded in battle, seeking the ability of nations and between nations, prevent and overcome the suffering of others.

2. Similarity, this movement does not make a distinction on the basis of nationality, ethnicity, religion / belief, degree, or political views. The goal is merely alleviating human suffering in accordance with their needs and prioritize state.

3. Impartiality, To always get the trust of all parties, this movement does not take sides or get involved in opposition politics, ethnicity, religion, or ideology.

4. Independence, this movement is independent. National Association besides helping the government in the humanitarian field must also comply with state regulations, must always maintain their autonomy so it can be aligned with this movement.

5. Voluntary Movement is a voluntary relief movement, which is not motivated by a desire for profit sharing.

6. Unity, In a country there is only one movement of the Red Cross or Red Crescent are open to everyone and carry out relief work throughout the region.

7. Universality, Movement of Red Cross and Red Crescent Societies is the nature of the universe. 
Every society has the right and the same responsibilities in helping fellow human beings. (http://www.pmimedan.or.id/profil/7-prinsipdasar-palang-merah-dan-bulan-sabit-merah/ accessed on 11 November 2016)

In the history of disaster management in Indonesia, where the Indonesian Red Cross organization itself became one among the many organizations and Non-Government Organizations (NGO) participating in disaster relief efforts with the Government and the community itself. PMI often find problems in disaster management.

In disaster management, will often encounter problems in implementation. Some of the problems that often arise in disaster management such as;

\section{a. Limited human resources}

Existing power generally have other routine tasks, human resources have not trained so it does not have the capacity to deal with disasters.

\section{b. Limited facilities and infrastructure}

Unavailability of shelter / service center for a number of large scale casualties. So some areas that have a history of significant disaster are encouraged to build shelters / shelters for refugees. But there are also areas that have associated cultural places that can be used as a refugee camp, such as the eruption of Mount Sinabung in Karo, local culture as jambur or homestead became a refuge despite having walls that are open, but at least a refuge while waiting for tents refugees.

\section{c. Health system}

Facilities and the health system has not provided specifically to cope with disasters, especially catastrophic potentially large number of victims. Hospital system in general has not been prepared to deal with large-scale disaster victims (Manurung, 2015)

For the eruption of Mount Merapi PMI already has a considerable role. This is indicated by the PMI's involvement in the disaster management cycle, from pre-disaster, disaster emergency response to the disaster. Some of them are in a state of pre-disaster, the PMI health service and the ambulance service of blood donation, disaster preparedness programs, community-based training emergency and community-based mitigation, Training Behavior Clean and Healthy Community Based, Forming a team of Disaster Preparedness Village (SIBAT), running a School Disaster Preparedness Programme, Synergy with Institutions/ NGOs in Disaster Efforts for Disaster Reduction. In an emergency disaster, not only in the eruption of Mount Merapi, PMI join in implementing coordination unit in the district / city and move under the coordination BPBDs, formed a Disaster Management Implementing Task Force (SATGANA). Team principal task is to carry out services PMI Satgana emergency response. In carrying out emergency response services guided by the Disaster Emergency Response Procedure PMI. And in the postdisaster phase, PMI made a post in the Karo district in the response to the eruption of Mount Sinabung which is still at the level of Awas. Due to the eruption of Mount Sinabung current phase of emergency response and post-disaster takes place simultaneously. This is indicated by the presence of the village as the village Bekerah, Simacem and Sukameriah that has entered the stage of relocation (post disaster) in Siosar, but some villages such as the village post Sigaranggarang still in refugee GBKP Six intersections. (Source data from processed researchers in the field)

Through this article, the author tries to explain how the form of participation in the PMI disaster relief efforts in Indonesia, particularly in the city of Medan.

\section{RESEARCH METHODOLOGY}

Research on PMI's role in disaster relief in the city of Medan using a qualitative approach to qualitative data analysis techniques where data collection using interviews. The location study is PMI in Medan, PMI in Medan there are two PMI and PMI Medan North Sumatra. And who became an informant for data collection was also taken in addition to the PMI staff interview data disaster victims, the victims interviewed were victims of a fire in the Gudang Arang, Village Belawan 1, District of Medan Belawan.

\section{DISASTER MANAGEMENT}

Disaster management is the responsibility of government and society. The disaster is not only the responsibility of the government, 
especially local government, but also a burden on the surrounding community. The role of the community is set in Perka BNPB No. 11 Year 2014 on Community Participation in Disaster Relief. Although the role of these communities do not become a liability for the community, but as a civilized nation, we ought to participate take a role in disaster management.

Perka BNPB No. 11 of 2014 states that the role of the community is the community involvement in the implementation, the implementation of disaster management in a planned, integrated, coordinated, and 'TOTAL in order to provide protection to msayarakat of threat risk and impact of disasters. Here also explained that people can make good associations are incorporated or not incorporated.

In Article 5 Perka BNPB No. 11 of 2014 stipulates that every person has a right. People here are people who are elements of society. Every citizen has the right, one of which is to get an education, training, and skills in disaster management. To accommodate the rights of citizens, PMI as a humanitarian organization formed Voluntary Force (TSR), Volunteer Corps (KRS), the Youth Red Cross (PMR), volunteer and Voluntary Blood Donor.

The involvement of citizens through the Red Cross in disaster relief, suggests that citizens begin to be aware of their role in disaster management. Disaster management have in the implementation process so often called disaster management. Khan (2008: 46) explains with a comprehensive definition of disaster management as "the sum total of activities, Programmes and measures the which can be talkken up before, during and after a disaster with the purpose to avoid disaster, reduce its impact or recover from its losses". Through this definition, Khan explained that disaster management is a number of activities, programs conducted before the disaster, the disaster is underway and after a disaster occurs.

Disaster risk reduction is in the predisaster stage through mitigation, early warning and preparedness. While there is protection in the response phase through; rapid assessment, a state of emergency, rescue and evacuation, fulfillment of basic needs and recovery, and disaster through social rehabilitation, rehabilitation of health, economic reconstruction, infrastructure, environment, security and order. Khan (2008: 47) gives the conclusion disaster management cycle in three stages, namely:

1. Before a disaster (pre-disaster). Pre-disaster activities Reviews those roomates are taken to reduce human and property losses, the caused by a potential hazard. For example, carrying out awareness campaigns, strengthening the exixting weak structures, preparation of the disaster management plans at household and community level, etc. such risk reduction measures are taken under this stage is termed as mitigation and preparedness activities.

2. During a disaster (disaster occurence). Reviews These include initiatives taken to Ensure that the needs of victims and provisions are met and Suffering is minimized. Activities taken under this stage are called emergency response activities.

3. After a disaster (Post-disaster). There are initiatives taken in response to a disaster with a purpose to Achieve early recovery and rehabilitation of affected communities, immediately after a disaster srikes. These are called as response and recovery activities.

If made in plain language, the disaster management cycle described by Khan is Stage Pre-Disaster Emergency Response Phase and Phase Post Disaster. It is the same as the definition of disaster management described by Khan earlier. Disaster management has a purpose, at the stage of pre-disaster, one aim is to prepare communities to deal with disasters, the response phase goal for the process to become effective disaster management and post disaster phase aim to restore the condition of refugees and improvement of infrastructure.

Etkin (2008: 15) concludes the purpose of disaster management as follows;

1. Minimize the loss, pain and damaged the caused by the disaster, within the larger social context,

2. Minimize the damaged the caused by disasters, while maintaining the structures of rights, power and wealth within society, as well as the instituitions that support them. 
Based on the above objectives disaster management, disaster management purposes can be summarized as measures to reduce risks, protect resources and carry out rehabilitation and reconstruction, through the disaster management includes the step of pre-disaster, emergency response and post-disaster.

Services PMI is generally composed of three services, namely Disaster Management Services, Health Services and Donor Services. For the city of Medan, Health Services PMI as the provision of free ambulance. Activities undertaken by the Indonesian Red Cross in Medan in the implementation of disaster management, from pre disaster, the relief phase to the post-disaster phase. Both the PMI and PMI Medan North Sumatra. Particularly in disaster management in the city of Medan described as follows:

\section{Pre-Disaster}

In service of disaster management at PMI, predisaster phase is included in disaster management ministry activities part of disaster preparedness. In the disaster preparedness of PMI nationally run programs Integrated Community Based Risk Reduction (PERTAMA), which is a community-based program to empower communities to idle capacity to prevent and mitigate the effects and risks of disasters at home. Society as a party directly affected by the time of the disaster must be empowered with the knowledge and ketrampulan sufficient, so as to make efforts in disaster mitigation and risk.

PERTAMA programs are implemented in areas prone to flooding, landslides, earthquakes, volcanic eruptions, tidal waves and tsunamis, and in areas where the public easy cooperation (gotong royong) to implement mitigation and risk reduction. PERTAMA programs include health: clean and healthy living awareness, improvement of water facilities, prevention of diseases caused by poor sanitation, dirty environment, water limbag and so forth. Economic sector: protection of agricultural land and ponds, livelihood improvement, and so on. Environmental field: the awareness for environmental conservation, protection of riverbanks, coastal management, repair drains, and so on. (http://www.pmi.or.id/index.php/aktivitas/pela yanan/manajemen-bencana/kesiapsiagaanbencana.html/acces on 13 November 2016)
In particular pre-disaster preparedness, PMI training as Emergency Patient Handling Training (PPGD) is the training on how to handle cases of life-threatening emergency. In order to deal with the gravity of the situation, hopefully everyone is able to give first aid to the right, so that the number of deaths in the provision of first aid can be minimized. Besides, there Skills Education Institute of Health was established in 1995. The Institute for Education and Skills (LPK) of Health is a participation PMI Medan city in the realm of education. PMI Medan City Institution for Education and Skills (LPK) of health has two main programs: One-year education program (for Assistant Paramedic) and Four months Education Program (Vocational Education and Family Care). The aim is to improve the quality of human resources in providing first aid, emergency victims and victims of natural disasters (assume the role of PMI contained in Permenkes RI No.23/ Birhub/1972 and Presidential Decree 246 of 1963)

(http://www.pmimedan.or.id/pelatihan/lembag a-pendidikan-dan-keterampilan-lpk-kesehatanpmi-kota-medan/ accessed on 12 November 2016)

But training is not routinely performed, while Institution for Education and Skills (LPK) of health over the role of PMI in tackling unemployment, so the role of Red Cross in disaster preparedness is not significant, it is undeniable that disasters often faced PMI Medan city as floods always come in the rainy season and fires. So the development of services in disaster preparedness is not a priority.

\section{Disaster Emergency Response}

In emergency relief PMI did a quick response, precise and coordinated to help people in time of disaster. For disaster management, supported by PMI volunteers prepared. PMI's mandate in assisting disaster management is contained in Presidential Decree (Decree) No. 25 Year 1950 and Presidential Decree No. 246 of 1963 on working PMI perform tasks on behalf of the government and accountable to the government to remain principled to the independence of the PMI and in the case of a disaster, PMI has the task, among others, before the disaster, during disaster and post-disaster.

In case of a fire that occurred in the Gudang Arang, Village Belawan, so no information fire 
occurs, immediately fell PMI volunteers conduct assessment. This is in accordance with the principles of PMI. PMI running principle "6 Hours Up in Disaster Area" that the initial response PMI has been done within 6 hours after the disaster occurred. This is to support PMI's response sought is done quickly, correctly, and coordinated.

After conducting the assessment, PMI followed up the results of the assessment. Such as providing the assistance needed by the victims of the fire. One of them is the provision of clean water, PMI provides a container of clean water (blue barrels), providing an ambulance near the site of the fire for a case if there are victims who must be evacuated to the hospital. PMI in the emergency response phase coordination with the Regional Disaster Management Agency.

Rapid reaction by sending volunteers to the disaster site became one of the hallmarks of the PMI, this makes PMI can directly provide assistance as needed in the field. PMI volunteers divided into two Volunteer Corps (KSR) and Voluntary Workers (TSR). KSR is a place of devotion for Ordinary Members and individuals who are self- selected claim to be members of KSR. And Power Voluntary (TSR) is a member of PMI were recruited from individuals from the community who professional backgrounds or have certain skills, such as doctors, nutritionists, sanitation, accountants, logistics, engineers, agriculture, journalist, artists/ performers, communication technology, teachers, and others.

In providing assistance to communities affected by the disaster, Red Cross provide services such as:

- Evacuate the victim

- Emergency shelter (refugee)

- First aid

- Medical and ambulance

- The common kitchen

- Distribution of aid

- Water and sanitation

\section{Post-Disaster (Recovery)}

PMI's involvement in the process of disaster recovery by helping to restore the lives of the people affected by the disaster. One of the services provided is the psychosocial support that aims to minimize the trauma experienced by the survivors of the disaster. PMI psychosocial support activities provided to children, adolescents, adults, to the elderly. The activities carried out were diverse, ranging from games, sports, agility, and counseling.

More on PMI services provided to disaster victims in the recovery period, namely:

- Psychosocial Support (Psychosocial Support Program)

- Shelter

- Restoration of Family Relations (Restoring Family Links)

\section{CONCLUSION}

The role of the Indonesian Red Cross in the city of Medan in disaster management is divided into three stages of disaster management services part of disaster preparedness, disaster response and post-disaster which focus on recovery. However the role of PMI in service activity is still dominated in disaster response. This is demonstrated by the quick reaction of PMI through volunteers who directly conduct an assessment in accordance with the principle of "6 hours until the location of disaster", providing assistance such as clean water services (water barrels net). While at the time of pre-disaster, the activity of PMI services performed is a blood donor services.

\section{RECOMMENDATIONS}

At the national level PMI many activities comprehensive disaster management services at the stage of disaster preparedness, emergency response and post-disaster (recovery), as shown by the disaster management ministry activities on the eruption of Mount Merapi. The hope PMI and PMI Medan North Sumatra could improve overall service at the three stages of disaster 
management. Special Medan ministry disaster management focused on disaster preparedness in view of frequent disasters faced by the city of Medan was the flooding that regularly come during the rainy season, so it is expected that PMI Medan in cooperation with the Government of Medan seeking solutions to displacement of people living in the outskirts of River Deli and Babura potentially disastrous.

\section{REFERENCES}

Etkin, David. (2007). The search for principles of disaster management. Toronto: York University

Khan, Himayatullah, (2008). Disaster management cycle a theoretical approach.
Pakistan: Institution Information Of Technology Abbottabad

Kodoatie, Robert. (2006). Analisa ancaman bencana hydro-meteorologis di Indonesia. Yogyakarta: Sheep Indonesia

http://www.pmi.or.id/index.php/aktivitas/pelay anan/manajemen-bencana/kesiapsiagaanbencana.html/accessed on 13 November 2016

http://www.pmimedan.or.id/pelatihan/lembaga -pendidikan-dan-keterampilan-lpkkesehatan-pmi-kota-medan/ accessed on 12 November 2016

http://www.pmimedan.or.id/profil/7-prinsipdasar-palang-merah-dan-bulan-sabitmerah/ accessed on 11 November 2016 